Bangl. J. Vet. Med. (2011). 9 (1) : 27-31

\title{
SEROLOGICAL SURVEY OF SALMONELLA INFECTION IN NON-VACCINATED COMMERCIAL LAYER BIRDS IN KHULNA DISTRICT OF BANGLADESH
}

\author{
M. A. Jalil ${ }^{* 1}$ and M. T. Islam ${ }^{2}$ \\ ${ }^{1}$ District Livestock Office, Khulna, ${ }^{2}$ Department of Medicine, Faculty of Veterinary Science, Bangladesh \\ Agricultural University, Mymensingh, Bangladesh
}

\begin{abstract}
A cross sectional study was conducted on 164120 non-vaccinated layer birds of 96 farms in six upazilas (Sadar, Batiaghata, Dumuria, Dighulia, Rupsha and Fultala) of Khulna district to determine the seroprevalence of Salmonella infection ( $S$. pullorum and S. gallinarum) during the period from August 2009 to July 2010. Sera samples were collected from 1268 layer birds of different ages and the birds were selected through a disproportionate stratified random sampling technique based on the flock size of each farm. Sera samples were tested by Serum plate agglutination (SPA) test applying commercial Salmonella antigen (Nobilis ${ }^{\circledR}$ SA, Intervet International B.V. Boxmeer- Holland) to detect the presence of antibodies against Salmonella. The overall seroprevalence of Salmonella infection was recorded as $65.9 \%$. The significantly higher seroprevalence (76.6\%) of Salmonella infection was recorded in layer birds of $>56$ weeks of age than those of other age groups. Seasons had significant influence on the seroprevalence of Salmonella infection. The seroprevalence was significantly higher in summer $(82 \%)$ than that in rainy $(66.8 \%)$ and winter $(50 \%)$ seasons. The location of farms, i.e. upazilas also had significant association with the occurrence of Salmonella infection. The seroprevalence significantly differed between the different categories of flock size. The flock size of 5001 and above had the highest seroprevalence (81.4\%) among other categories. It may be concluded that above 60\% layer birds in 92 out of 96 farms are infected with Salmonella organism, which requires keeping of vigilant eye of the poultry farmers and the hatchery owners in the control of Salmonella infection in poultry farms.
\end{abstract}

Key words: Seroprevalence, Salmonella infection, serum plate agglutination (SPA), layer birds

\section{INTRODUCTION}

As in other poultry producing countries, salmonellosis is one of the important disease problems for poultry in Bangladesh, both for commercial exotic breeds and indigenous local breeds (Rahman et al., 2004; Saleque et al., 2003; Sikder et al., 2005). Infections of poultry with salmonellae are caused by two groups of serotypes, i) two nonmotile serotypes $S$. pullorum and $S$. gallinarum and ii) the numerous motile Salmonella serotypes (paratyphoid salmonellae). Infections with serotypes of first group have been responsible for serious economic losses to poultry producers and have been addressed by the implementation of extensive testing and eradication programs (Gast, 2003). Although in all types of poultry production, infection by Salmonella can occur during any part of the production cycle (Byrd et al., 1999; Bailey et al., 2002), it is likely that in both broilers and layers most of the initial infection takes place early post-hatch, as a result of hatchery contamination or persistent farm contamination. Infection of very young chicks results in high levels of environmental contamination and rapid transmission of pathogens as a result of litter contamination (Van Immerseel et al., 2005).

A definitive diagnosis of Salmonella infection (S. pullorum and S. gallinarum) requires the isolation and identification of the Salmonella organisms. However, a tentative diagnosis can be made based on the flock history, clinical signs, mortality and lesions. Positive serological findings can also be of great value in detecting infection (Shivaprasad, 2003). Serological tests such as the macroscopic tube agglutination (TA) test, whole blood agglutination test, serum plate agglutination (SPA) test, and enzyme-linked immunnosorbent assay (ELISA) have been used to detect Salmonella organism (Barrow, 1992; Gast, 1997; Feberwee et al., 2001; Jalil and Islam, 2010). Of these tests, the TA and SPA tests are commonly used for detection and removal of reactor birds in the control programme of salmonellosis.

*Corresponding e-mail address: maj_dvm@yahoo.com

Copyright ㄷ 2011 Bangladesh Society for Veterinary Medicine

All right reserved 1729-7893/0219/2011 


\section{A. Jalil and M. T. Islam}

Much work has been done on the prevalence of Salmonella infection in chickens in many countries of the world. However, there were wide variations in selecting target population, sample size, test procedure etc. In Bangladesh, a good number of works has been done on the prevalence of Salmonella infection based on isolation, identification and serological tests in Rajshahi, Gazipur, Patuakhali districts (Saleque et al., 2003; Rahman et al., 2004; Sikder et al., 2005; Hossain et al., 2006; Islam et al., 2006; Hossain et al., 2010). However, more survey on the seroprevalence of Salmonella infection covering wide geographical areas of Bangladesh is required to plan effective control programme. The objective of this study was to determine the seroprevalence of Salmonella infection (S. pullorum and S. gallinarum) in non-vaccinated layer birds in Khulna district.

\section{MATERIALS AND METHODS}

\section{Study population and sampling}

A cross sectional study was conducted on 164120 commercial layer birds of 96 farms in six upazilas (Sadar, Batiaghata, Dumuria, Dighulia, Rupsha and Fultala) of Khulna district during the period from August 2009 to July 2010. A total of 1268 layer birds of different ages were selected through a disproportionate stratified random sampling technique based on the flock size of each farm. Blood samples without any anticoagulant were collected aseptically from wing vein of the selected birds and sera were separated and stored at $-20^{\circ} \mathrm{C}$ until used.

\section{Salmonella antigen}

Salmonella antigen (Nobilis ${ }^{\circledR}$ SP, Intervet International) was used for rapid plate agglutination (RPA) test to detect antibodies due to infections caused by both standard and variant strains of Salmonella pullorum and Salmonella gallinarum in the sera samples.

\section{Rapid plate agglutination (RPA) test}

The RPA test was conducted according to the manufacturer's instruction. Briefly, $0.02 \mathrm{ml}$ of antigen and 0.02 $\mathrm{ml}$ of chicken serum were placed side by side with micropipettes on a glass plate. After that antigen and serum sample were mixed thoroughly by stirring with a small tooth pick. Then the glass plate was illuminated from below so as to facilitate observing the reaction, avoiding excessive heat from the light source. Positive reaction was characterized by the formation of definite clumps within 2 minutes after mixing the test serum with antigen. The clumps usually started appearing and became concentrated at the periphery of the mixture. Negative reaction was judged by the absence of agglutination reaction. Care was taken so that no natural granulation of the antigen could be taken as a positive reaction.

\section{Statistical analysis}

In order to study the temporal distribution of the disease, the year was divided into four quarters viz. JulySeptember (A), October-December (B), January- March (C) and April-June (D). Quarters B and C comprised of the winter season; D, the summer season and A, the rainy season. The data so collected were analyzed statistically using Z test for proportions to draw the inferences (Beri, 2005).

\section{RESULTS AND DISCUSSION}

Of the 1268 birds screened from 96 flocks, 835 (65.9\%) birds tested positive to Salmonella antibodies, i.e. the overall seroprevalence of Salmonella infection was $65.9 \%$ (Table 1). The present finding is discordant with two inland reports of Islam et al. (2006) and Hossain et al. (2010) who observed 43.4\% and 25.3\% seroprevalence in Dhaka-Gazipur and Rajshahi, respectively. Geographical variation or difference in management practices might be the cause of variation in the seroprevalence (Sikder et al., 2005; Islam et al., 2006). However, the present finding is concordant with an overseas report of Ashenafi et al. (2003) who reported 64.2\% seroprevalence in local chickens of Central Ethiopia. 
Table 1. Seasonal influence on the seroprevalence of Salmonella infection in layer birds in six upazilas of Khulna district

\begin{tabular}{lllll}
\hline Seasons & Population & No. of samples tested & No. of samples positive & Prevalence $(\%)$ \\
\hline Summer & 54650 & 383 & 314 & $82.0 \mathrm{a}$ \\
Rainy & 55570 & 467 & 312 & $66.8 \mathrm{~b}$ \\
Winter & 53900 & 418 & 209 & $50.0 \mathrm{c}$ \\
\hline Total & 164120 & 1268 & 835 & 65.9 \\
\hline
\end{tabular}

Values with different letters within a column differ significantly at $\mathrm{p}<0.05$.

There was significant influence of seasons on the seroprevalence of Salmonella infection in layer birds. The seroprevalence of Salmonella infection was significantly higher in summer (82\%) than that in rainy $(66.8 \%)$ and winter $(50 \%)$ seasons. Similar findings were reported by Hossain et al. (2010) who recorded higher seroprevalence in summer $(30.4 \%)$ followed by rainy $(25.0 \%)$ and winter $(23.7 \%)$ seasons. The higher seroprevalence of Salmonella infection in summer (48.1\%) than in winter (23.7\%) was also reported by Rahman et al. (2004). The highest rate of Salmonella infection in summer season may be due to increase in bacterial growth in summer and the influence hot weather that might reduce the immune status of birds against infection (Sikder at al., 2005; Hossain et al., 2010).

Table 2. Age-wise seroprevalence of Salmonella infection in layer birds in six upazilas under Khulna district

\begin{tabular}{|c|c|c|c|c|c|c|c|c|}
\hline \multirow[t]{3}{*}{ Upazilas } & \multicolumn{8}{|c|}{ Seroprevalence of Salmonella infection } \\
\hline & \multicolumn{2}{|c|}{ Pullet (8-20 wks) } & \multicolumn{2}{|c|}{ Layer (21-56 wks) } & \multicolumn{2}{|c|}{ Layer $(>56$ wks $)$} & \multicolumn{2}{|c|}{ Overall } \\
\hline & No. tested & $\frac{\text { Prevalence }}{\text { No. }(\%)}$ & No. tested & $\frac{\text { Prevalence }}{\text { No. }(\%)}$ & No. tested & $\begin{array}{c}\text { Prevalence } \\
\text { No. }(\%)\end{array}$ & No. tested & $\frac{\text { Prevalence }}{\text { No. }(\%)}$ \\
\hline Sadar & 137 & $74(54.0)$ & 333 & $179(53.8)$ & 163 & $99(60.7)$ & 633 & $352(55.6) \mathrm{a}$ \\
\hline Batiaghata & 27 & $24(88.9)$ & 269 & $190(70.6)$ & 43 & $41(95.3)$ & 339 & $255(75.2) \mathrm{b}$ \\
\hline Dumuria & 6 & $6(100.0)$ & 43 & $16(37.2)$ & 0 & $0(0)$ & 49 & $22(44.9) \mathrm{a}$ \\
\hline Dighulia & 29 & $23(79.3)$ & 45 & $35(77.8)$ & 44 & $44(100.0)$ & 118 & $102(86.4) \mathrm{b}$ \\
\hline Rupsha & 3 & $1(33.3)$ & 66 & $56(84.9)$ & 15 & $12(80.0)$ & 84 & $69(82.1) b$ \\
\hline Fultala & 0 & $0(0)$ & 15 & $5(33.3)$ & 30 & $30(100.0)$ & 45 & $35(77.8) b$ \\
\hline Total & 202 & $128(63.4) a$ & 771 & $481(62.4) \mathrm{a}$ & 295 & $226(76.6) b$ & 1268 & $835(65.9)$ \\
\hline
\end{tabular}

Values with different letters within a column as well as a row differ significantly at $\mathrm{p}<0.05$.

Regarding the age of birds, significantly higher seroprevalence (76.6\%) of Salmonella infection was recorded in layer birds of $>56$ weeks of age than those of other age groups. However, no significant difference was observed in seroprevalence between birds of 8-20 weeks old and 21-56 weeks old (Table 2). The increased seroprevalence of Salmonella infection in aged layer birds corresponds with the report of Islam et al. (2006) who reported higher prevalence $(72.9 \%)$ of Salmonella infection in layer birds of $>60$ weeks old than those of any other age group. It has been reported that the prevalence of Salmonella infection increased with the increase of age of birds (Truong and Tieuquang, 2003; Hossain et al., 2010). Rahman et al. (2004) reported highest infection rate with Salmonella in adult layers $(53.25 \%)$ in comparison to brooding (14.55\%), growing (16.10\%) and pullet $(16.10 \%)$ chickens.

In relation to study area, there was significant variation was recorded in the seroprevalence of Salmonella infection among farms of six upazilas $(\mathrm{p}<0.05)$. The significantly highest $(86.4 \%)$ prevalence of Salmonella infection was in Dighulia upazila and lowest (44.9\%) in Dumuria upazila (Table 2). The day-old chicks of different farms in six upazilas were purchased from different hatcheries and the management practices in those farms were also different, which might be the probable factors for variation in the seroprevalence. 
Table 3. Influence of flock size on the seroprevalence of Salmonella infection in layer birds in six upazilas of Khulna district

\begin{tabular}{lcccc}
\hline Flock Size & No. of flocks & No. of samples tested & No. of samples positive & Prevalence $(\%)$ \\
\hline $500-2000$ & 76 & 703 & 455 & $64.7 \mathrm{a}$ \\
$2001-3500$ & 13 & 297 & 196 & $66.0 \mathrm{a}$ \\
$3501-5000$ & 4 & 139 & 79 & $56.8 \mathrm{a}$ \\
$5001-$ above & 3 & 129 & 105 & $81.4 \mathrm{~b}$ \\
\hline Total & 96 & 1268 & 835 & 65.9 \\
\hline
\end{tabular}

Values with different letters within a column differ significantly at $\mathrm{p}<0.05$.

The seroprevalence of Salmonella infection significantly $(\mathrm{p}<0.05)$ differed between the different categories of flock size (Table 3). The seroprevalence was significantly higher (81.4\%) in the flock size of 5001 and above than any other category of flock size. However, no significant difference was found between the other three categories of flock size (500-2000, 2001-3500 and 3501-5001). This finding is in agreement with the findings of Hossain et al. (2010) who reported the higher (34.2\%) seroprevalence of Salmonella infection in large flocks ( $\geq 5001$ birds) in comparison to $21.3 \%$ in small flocks ( $\leq 1000$ birds). The highest infection rate in large flocks may be due to the high flock density, which facilitate easy spread of any infection. Besides, error in management practices is not unlikely in large flocks that may contribute to the increase in seroprevalence of Salmonella infection (Hossain et al., 2010).

It may be concluded that above $60 \%$ layer birds in 92 out of 96 farms are infected with Salmonella organism, which requires keeping of vigilant eye of the poultry farmers and the hatchery owners in the control of Salmonella infection in poultry farms.

\section{REFERENCES}

1. Ashenafi H, Shetu Y and Oldemeskel M (2003). Identification of major infections of local chickens of central Ethiopia. Bulletin of Animal health and Production in Africa 51: 95-101.

2. Bailey JS, Cox NA, Craven SE and Cosby DE (2002). Serotype tracking of Salmonella through integrated broiler chicken operations. Journal of Food Protection 65: 742-745.

3. Barrow PA (1992). ELISAs and the serological analysis of salmonella infections in poultry. A review. Epidemiology and Infection 109: 361-369.

4. Beri GC (2005). Business Statistics. $2^{\text {nd }}$ edn., Tata McGraw-Hill Publishing Co. Ltd., New Delhi, India.

5. Byrd JA, DeLoach JR, Corrier DE, Nisbet DJ and Stanker LH (1999). Evaluation of Salmonella serotype distributions from commercial broiler hatcheries and grower houses. Avian Diseases 43: 774-778.

6. Feberwee ATS, Hartman EG, Wit JJ, Elbers ARW and De jong WA (2001). Vaccination against salmonella enteritidis in Dutch commercial layer flocks with a vaccine based on a live Salmonella gallinarum 9R strain: evaluation of efficacy, safety and performance of serologic salmonella test. Avian Disease 45: 83-91.

7. Gast RK (1997). Detecting infections of chickens with recent Salmonella pullorum isolates using standard serological methods. Poultry Science 76: 17-23.

8. Gast RK (2003). Salmonella Infections. In: Saif YM, Barnes HJ, Glisson JR, Fadly AM, McDougald LR and Swayne DE (eds.). Iowa State Press, USA. p. 567.

9. Hossain KMM, Hossain MT and Yamato I (2010). Seroprevalence of Salmonella and Mycoplasma gallisepticum infection in Chickens in Rajshahi and surrounding District of Bangladesh. International Journal of Biology 2(2): 74-80.

10. Hossain MS, Chowdhury EH, Islam MM, Haider MG and Hossain MM (2006). Avian salmonella infection: isolation and identification of organisms and histopathological study. Bangladesh Journal of Veterinary Medicine 4: 07-12.

11. Islam MM, Haider HG, Chowdhury EH, Kamruzzaman M and Hossain MM (2006). Seroprevalence and pathological study of salmonella infections in layer chickens and isolation and identification of causal agents. Bangladesh Journal of Veterinary Medicine 4(2): 79-85. 
12. Jalil MA and Islam MT (2010). A cross-sectional study for Mycoplasma gallisepticum antibodies in non vaccinated commercial layer birds in Khulna district. Bangladesh Journal of Veterinary Medicine 8(2): 93-96.

13. Rahman MA, Samad MA, Rahman MB and Kabir SML (2004). Bacterio-pathological studies on salmonellosis, colibacillosis and pasteurellosis in natural and experimental infections in chickens. Bangladesh Journal of Veterinary Medicine 2(1): 1-8.

14. Saleque MA, Rahman MH and Hossain MI (2003). Seasonal variation in the prevalence of poultry diseases in Bangladesh. Ninth BSVER Annual Scientific Conference held at BAU, Mymensingh, BSVER publication 24: 23-24.

15. Shivaprasad HL (2003). Pullorum Disease and Fowl Typhoid. In: Saif YM, Barnes HJ, Glisson JR, Fadly AM, McDougald LR and Swayne DE (eds.). Iowa State Press, USA. pp. 568-582.

16. Sikder AJ, Islam MA, Rahman MM and Rahman MB (2005). Seroprevalence of Salmonella and Mycoplasma gallinarum infection in the six model breeder farms at Patuakhali district of Bangladesh. International Journal of Poultry Science 4: 905-910.

17. Truong Q and Tieuquang AN (2003). Prevalence of Salmonella gallinarum pulorum infection in the Luong Phuong chickens reared in the household sector. Khoa-Hoc-Ky-Thuat-Thu-Y-Veterinary-Sciences-and-Techniques 10: $15-19$.

18. Van Immerseel F, Methner U, Rychlik I, Nagy B, Velge P, Martin G, Foster N, Ducatelle R And Barrow PA (2005). Vaccination and early protection against non-host-specific Salmonella serotypes in poultry: exploitation of innate immunity and microbial activity. Epidemiology and Infection 000: 1-20. 